\title{
FORMING A MUTUALLY RESPECTFUL UNIVERSITY-COMMUNITY PARTNERSHIP THROUGH A “FAMILY AS FACULTY” PROJECT
}

\section{CRISTINA SANTAMARÍA-GRAFF AND JOEL BOEHNER}

\section{ABSTRACT}

In this paper, we, a university special education professor and an executive director of a parent-toparent non-profit organization, describe our collaborative partnership built on a common understanding that parents of children with disabilities are educational leaders. We address how we work collaboratively to locate and establish families as coeducators in an undergraduate special education course on families for pre-service special education teachers by using a Family as Faculty (FAF) approach. We use narrative inquiry as a methodology to detail shared moments and individual thinking about entering into this partnership. Through our narratives, we detail the ways in which we have worked together to construct a solid foundation for the first and subsequent FAF projects rooted in communityengaged participatory research. We highlight the ways in which our partnership began through establishing trust, respect, and clear, common goals. These mutually created goals are tied to specific outcomes that include: a) parent leadership in higher education settings, b) greater pre- and in-service special education teacher awareness of family rights and advocacy, and c) on-going structured commitments by both the university professor and the executive director to support each other's projects and organizations. Finally, processes and outcomes centered around FAF are built on values such as reciprocity, mutual respect, and sustainability. Family as Faculty's success is ensured only to the degree that stakeholders are committed to these values and are honest with each other about their roles in FAF at any given moment.

Keywords: university-community partnerships, Family as Faculty, collaboration, community-engagement, special education, disabilities, family engagement, reciprocity

FORMING A MUTUALLY RESPECTFUL UNIVERSITY-COMMUNITY PARTNERSHIP THROUGH A "FAMILY AS FACULTY" PROJECT

This is a narrative of events relating the ongoing community-engaged, professional partnership between a university professor of special education and an executive director of a parent-to-parent non-profit organization. In relating our story, we hope to provide context for ways to establish and maintain a sustainable community partnership that is mutually beneficial for all stakeholders. We present this information as a narrative of our lived experiences, giving special weight to understandings about partnership that emerge from these tellings. We begin with who we are and our first correspondence and end with where we are now as we enter our third year of continued commitment to the families of children with disabilities whom we serve. We use narrative inquiry 
within this paper to tell our stories, but on a larger scale, embedded within the Family as Faculty project, the methodology used to enter into and sustain our partnership is rooted in community-engaged participatory research (described in a later section). Narrative inquiry as a storytelling tool is helpful in describing our experiences using a combination of first- and third-person voice. We use first-person singular to reflect upon our own stories, first-person plural to demonstrate our shared experiences, and third-person singular to distinguish our unique roles in this partnership. Though we structure our narrative through a linear progression of events, we also interweave critical self-reflections residing outside or on the periphery of actual events. These insights illuminate underlying metanarratives or self-reflection focused on power and privilege and the ways we grapple with our distinctive positionalities or identities in relation to one another and to the community members and families with whom we interact. For clarity, some of the terms used in this paper are unpacked in Figure 1.

\section{Figure 1:}

Concepts and Terminology Defined

Equity

Within the context of partnership, equity is achieved when all stakeholders feel represented as full participants in the project, when power is fairly and evenly distributed, and when mutually created goals and intended outcomes are honored, acted upon, and/or realized.

Mutual respect

Within the context of partnership, mutual respect is viewing and treating the partner as an equal decision-maker and stakeholder. It is also the feeling of authentic trust that is engendered through gestures, words, and actions centered in a 2-way appreciation of one another's strengths and assets each person is bringing to the project.
Positionality

Power

Privilege

Reciprocity

Sustainability

Our stories narrate our experience of and involvement in Family as Faculty (FAF) approaches. Family as Faculty is a term to describe an approach to teaching or research in which family members take on leadership roles, teach others through their insider perspectives, and broaden understandings of those 
who are working with or for their children (Heller \& McKlindon, 1996; Johnson, Yoder, \& RichardsonNassif, 2006). These approaches originate from familycentered healthcare models and have been adapted in special education teacher education programs to influence and impact pre-service special education teachers' dispositional understandings of working and collaborating with parents/families of children with dis/abilities ${ }^{1}$ (Forlin \& Hopewell, 2006; Macy \& Squires, 2009; Patterson, Webb, \& Krudwig, 2009; Williams, 2012). Specifically, we are interested in ways that FAF approaches can center family leadership and knowledge in special education teacher education courses and programs while, at the same time, provide structured opportunities for family members to expand upon their roles as advocates for their children and for other families (Warren-Gordon \& Santamaría Graff, 2018).

\section{NARRATIVE INQUIRY}

To describe our partnership within the context of FAF we use narrative inquiry. Narrative inquiry is based on the premise that "stories are lived, and told, not separated from each person's living and telling in time, place, and relationships" (Clandinin, Cave, \& Berendonk, 2017, p. 91). It is a relatively new qualitative methodology that centers individuals' stories as a way of making meaning of larger phenomena (Clandinin \& Huber, 2010). Through storytelling, tensions can arise that shed light on specific challenges that are told,

\footnotetext{
${ }^{1}$ Disabilities with a slash (/) refers to the social construction of identity, rather than fixed, immutable traits. How meaning is attached to ability is, oftentimes, more disabling than the dis/ability itself due to the ways dominant mainstream society has normalized the conditions for ability and able-bodiedness (Davis, 1995; Davis 2013). In this paper, disability is
}

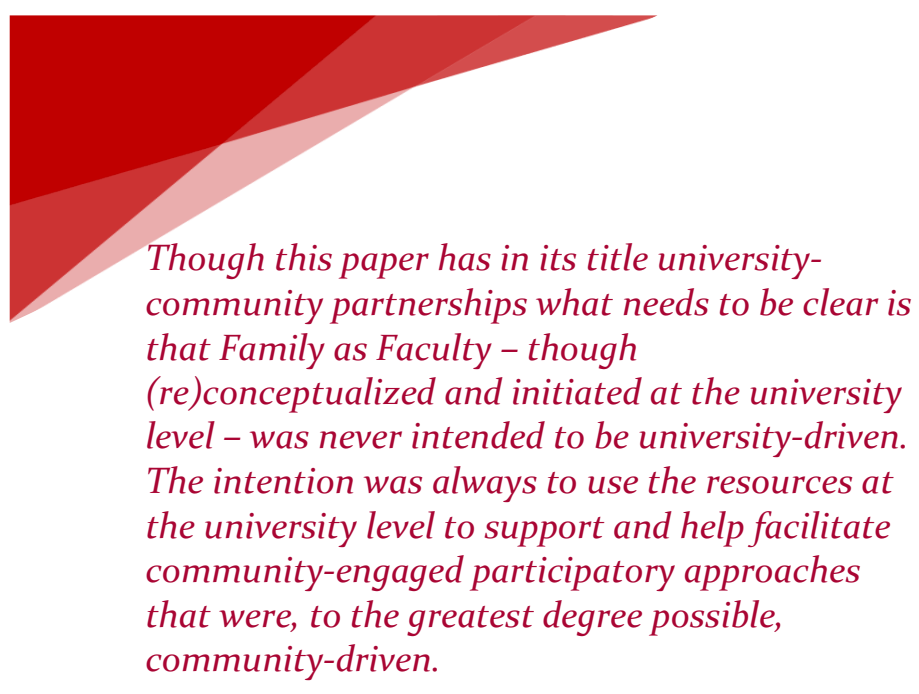

talked through, reflected upon, and examined (Clandinin \& Rosiek, 2007). This method is particularly useful in analyzing the complexities of partnership in forming and building a collaborative relationship that is both unique to our personal, lived experience as well as informative for others outside of this inquiry who are engaged similarly.

We structure our narratives through a backand-forth descriptive (re)telling of events that occurred between 2016 - 2018. To capture these events in written form, we pulled from a number of primary and secondary sources that included: a) notes from meetings we both attended, b) notes from informal conversations, c) materials from a conference presentation we were both involved in, and d) reflective writings about our partnership. Additionally, for this paper, we shared our writing in a Google document and were able to provide one another

written with a slash in specific references to children or students with dis/abilities. 
feedback over the course of two months as we engaged in written correspondence about our partnership.

Themes that emerged included the importance of mutual goals and values of respect, reciprocity, and sustainability. Underlying these goals and values were some tensions, namely how each of our roles in relation to one another and to the partnership brought up concerns around privilege and power. These goals, values and tensions are discussed and interwoven in subsequent sections.

COMMUNITYENGAGED

\section{PARTICIPATORY}

\section{RESEARCH}

\section{Although}

we use narrative inquiry as a tool to share our lived experiences, the Figure 2 Community Partnership Continuum \& Terminology

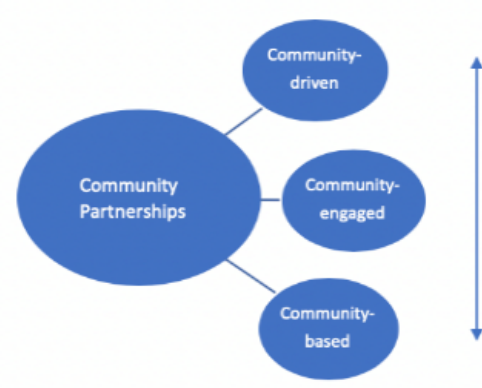

More power centered in the community

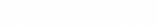

(a)

(n)


- Who holds the power? In other words, who is driving the research questions, research design, data collection, implementation, and dissemination of research outcomes?

\section{WHO WE ARE}

In this section we begin by describing who we are, our backgrounds, and what brought us to our current work in a long-term, community-engaged partnership.

\section{Cristina}

I am a female professor in special education at a university in the Midwest who has been an educator for over twenty years. I self-identify as a biracial Mexicana which, to me, means that I come from a mixed-race background. My father is Mexican and my mother comes from Italian/Irish heritages. For me it is critical to self-identify who I am in my work so that others understand how I foreground my biracial background in what I do professionally. Research-wise I have chosen to work with families of children with dis/abilities, particularly Latinx families. Many of the families with whom I work and collaborate with are immigrants (Santamaría Graff, McCain, Gomez-Vilchis, 2013; Santamaría Graff \& Vazquez, 2014). Being forthright and transparent about my positionality as an able-bodied mother of non-disabled children and as a biracial, bilingual (but English-dominant), educated female in higher education is important in acknowledging the privilege that comes with each of these identity markers. More important, is the constant critical self-reflection I undergo in checking my own ego and power as I engage with community partners who, oftentimes, are parents of children with dis/abilities.

\section{Joel}

I am a male executive director of a parent-toparent non-profit organization, IN*SOURCE. I have served in this role for just over a year and have been with this organization for three years. While what most characterized my upbringing was my family's conservative evangelical Christian religiosity, what has come to most characterize my identity as an adult is how I identify in relation to my children. I am a white non-disabled foster/adoptive father to two AfricanAmerican children with special needs. Understanding their stories before and after they entered my life shapes my understanding of privilege in an ongoing manner.

Professionally, I am the highest-ranking employee in an organization of about fifty employees nearly all of whom are parents of children with dis/abilities. IN*SOURCE is a parent center with federal and state funding sources. Our founding is rooted in the disability rights movement and the activist efforts of the disability community to establish a place in public education for students with dis/abilities. Our work is based on and informed by power dynamics and privilege as it affects the disability community, particularly students with dis/abilities and their parents.

Leading a parent center demands a publicly expressed identity where personal experience informs and legitimizes professional judgment. I don't think I could do my work without frequent self-identification, yet my identity as a father drives my professional life 
and is my defining passion. I am often the de facto or official parent representative in meetings of systemic importance where a parent's perspective is necessary or desired, and this representative role challenges me and informs my approach to collaborative efforts. The representative role that I play and that IN*SOURCE plays in the scheme of special education in my home state challenges me to seek ways of more and more thoroughly equipping all families to advocate for their children. Without explicit attention on systemic inequities beyond disability such as opportunity gaps facing communities of color and non-English-speaking communities, for example, our role as a representative is problematized. My personal experience in a transracial family is the basis of my understanding of privilege and that perspective drives my professional judgment as a de facto or official parent representative.

\section{CONTEXT OF OUR PARTNERSHIP}

\section{Cristina}

Over two and a half years ago after I moved to a major metropolitan city in the Midwest to become a professor at a research institution, I decided I wanted to dive more deeply into community-engaged work with families of children with dis/abilities. To do this, I relied heavily on my previous experiences as a doctoral student in the Southwest United States and as an Assistant Professor in the Northwest. In both regions, I had the opportunity to work with Latinx families (Santamaría Graff, McCain, \& Gomez-Vilchis, 2013). In the Southwest, however, I was able to work closely with a parent-to-parent organization that assisted me in recruiting Latina mothers of children with dis/abilities. I soon discovered through this work that these Latina mother-advocates were experts about issues that impacted their children. I quickly learned that to work with these mothers meant I needed to be an active listener and learner who, in spite of my education, knew little about what it was to be a parent of a child with dis/abilities (Santamaría, 2009).

Having had this positive previous experience with the Southwest parent-to-parent organization, I decided, when I started working in the Midwest, to reach out to two parent-to-parent organizations. One was situated locally and the other's main office was in the northern part of the state about 150 miles away from where I was living and working. My first step was to research each organization's mission statements and to find out if their goals and values were in alignment with mine. Though both organizations responded positively to my initial emails, this narrative only describes the experience I've had with one of these organizations, specifically my interactions with IN*SOURCE.

\section{Joel}

When I first came to IN*SOURCE, my job was to manage one of our grants. In this role I supervised as many as fourteen staff which included supporting personnel in a major Midwest metropolitan area. The grant I managed included deliverables around "outreach" efforts to historically underserved populations including families with incarcerated youth with dis/abilities, low income families, and nonEnglish-speaking families. In order to support families whose primary language is Spanish, we employ staff who are bilingual in Spanish and English. Prior to any 
awareness of FAF or relationship with Cristina, IN*SOURCE bilingual staff had observed enough systemic shortcomings with respect to Spanishspeaking access to special education information that they had begun to work with IN*SOURCE administration to raise further awareness of this problem. The solution that emerged from conversations with bilingual program specialists centered around the need for IN*SOURCE to present the data and stirring anecdotes to our State Educational Agency (SEA) along with a request for a funding package that would support work training interpreters for special education.

I was personally affected by the stories our staff had accumulated through their work with Spanishspeaking families that involved unprofessional disclosures of private information, consequential technical details being misrepresented, conflicts of interest being unaddressed, and Local Educational Agencies (LEAs) able to abide by the letter of special education law without being equipped to know whether an interpreter is properly qualified for their important work. My work with bilingual staff to develop a solution that addressed the known issues and that the SEA would be able to support with funding brought me into a new place professionally. With the support of the Executive Director, IN*SOURCE engaged the state office of special education around this concern culminating in a successful "pitch" to the state director of special education for support of this project as an additional node to our ongoing work with them.
As a statewide organization, IN*SOURCE often is contacted by researchers who are pursuing studies that relate to disability and special education. We have varying degrees of involvement with scholars and institutions of higher education that range from participating in studies mutually designed with our feedback and access to families we work with in mind to the all too pervasive mass email with a link to a survey. If the study seemed particularly relevant, I would pursue the author requesting our support with some follow-up questions designed to get at their approach to working with families with special needs and even more basically whether they cared enough to answer my questions. I learned that almost always, the mass email was not intended to elicit substantial follow-up conversations. It is in this context that I learned of training requests from a professor of special education whose approach to working with our staff and her students particularly valued something that we too value--the importance of a parent's perspective in their child's special education. It was through staff involvement in a "training" capacity to Cristina's students that led to a request for more formal, more integrated support of Cristina's research emphasis, the FAF study. Cristina's approach and methods were a welcome contrast to the much more common transactional approach.

\section{ESTABLISHING MUTUAL TRUST AND RESPECT}

In the following narratives, we discuss the first time we met. Our stories highlight the importance of entering into partnership with trust, respect, and clear, common goals. These goals center on family member leadership and ways that family members are 
positioned in FAF projects to assist future teachers in their understanding of families as resourceful partners or allies. In this section, the value of mutual respect is integral in establishing a foundation for strong collaboration and communication.

\section{Cristina}

My first email correspondence with Joel focused on my conceptualization of Family as Faculty (FAF) and the ways I believed IN*SOURCE could be a key stakeholder in its organization and implementation. In the email, I introduced myself and provided IN*SOURCE with a draft of the Internal Revenue Board (IRB) proposal in which I described the mixed methods study I intended to implement through a FAF approach. I hoped that sharing the proposal with Joel and other IN*SOURCE members would engender trust. I provided them with the context for and purpose of the FAF study as well as give details about the ways I was positioning parents as teacher-leaders in my special education course. I wanted to demonstrate my commitment to the parents associated with their organization. I believed that a definitive plan with specific procedures and a timeline would provide IN*SOURCE members with the opportunity to critique the project and give feedback.

In the email I sent to Joel and IN*SOURCE, I not only sent the IRB draft proposal but also I specifically asked if IN*SOURCE could provide me with access to families' emails so I could contact them to see if they would be interested in the FAF project. Joel shared the draft with the former IN*SOURCE Executive Director and a few days later, after perusing the document, they asked if they could meet with me face-to-face.

We met downtown in a hotel café where they were attending a state conference. Over coffee, both Joel and the former Executive Director seemed happy to meet with me and, at the same time, asked me pointed questions about the breadth and scope of my involvement with parents. Though asked with respect and politeness, Joel centered his questions carefully around specific protections I would be providing for parents who might be interested in participating in the study. I remember thinking how important it was for me to provide in-depth answers to his questions because he seemed to have concerns around how parents or family members may be exposed in public or academic settings. Both Joel and the Executive Director were clear that if they were to assist me in the recruitment of parents for my study, they needed to be assured parents were in good hands. In other words, I needed to demonstrate "good faith" by providing them with clearly written procedural steps, goals, and outcomes as documented in my proposal and throughout the project.

I remember describing the purpose of the FAF study and receiving an encouraging response by the Executive Director who said that our goals were "in alignment." What I believe he meant was that my intentional positioning of parents and families as experts of their children was central to IN*SOURCE's goals as well. Specifically, it appeared he shared my view that families' innate and experiential knowledge of their children was an important component of their advocacy. The Executive Director and Joel extended 
their support by offering to assist me in recruiting parents through their Listserv. I crafted a "recruitment" email asking for voluntary parent participation, submitted it to IRB for approval, and then sent it to IN*SOURCE. The Executive Director and Joel approved of the language in the email and sent the email out to approximately 100 families affiliated with IN*SOURCE. This gesture was significant because they sent the information from IN*SOURCE's official email and signaled to recipients that they approved of my study.

Moreover, because parent/family recipients trusted IN*SOURCE as an organization, they, in turn, trusted me because I was now directly affiliated with IN*SOURCE.

\section{CONSIDERATION OF STEPS}

Some of the ways that mutual trust and respect were established are listed in Figure 3 as delineated through specific steps. These "steps" are not formulaic nor are they always linear. Cristina's story highlights the ways she initiated contact with IN*SOURCE and the steps she considered before and during the initial meeting with Joel. Joel's narrative below illustrates the careful consideration he took to ensure that IN*SOURCE's parents' and families' best interests were being accounted for before committing to the Family as Faculty project. Both perspectives are reflected in Figure 3's "Steps" and may be helpful for those who are considering entering into university or higher education - community partnerships.

Figure 3:

Steps in Establishing Mutual Respect and Trust
1. Know who you are and what you stand for. You should be able to articulate this orally or in writing succinctly.

2. Know the purpose and mission of your project/organization and be prepared to articulate this for your community or university partner or other stakeholders.

3. Do your homework. Before establishing contact, research the partner's information. Whether it is a Curriculum Vita, an organization's mission statement, or individuals' biographies, find out if your work is in alignment with theirs.

4. Learn key players' names and their positions before meeting with them, if possible.

5. Reach out in appropriate ways and through the proper channels. Establish parameters for communication. Demonstrate courtesy and respect in email and phone correspondence and in face-to-face interactions.

6. Be open and gracious when meeting and interacting with your partner. Allow one another to speak without interruptions and without set expectations. The process should flow with space for negotiation.

7. Allow expansion of your ideas. In line with number 6 , a partnership should be given room to grow rather than feel forced, closed, or fixed.

8. Discuss alignment of one another's purpose or mission. Here, transparency is key. Be upfront about number 2 with your (potential) partner and actively listen to their responses.

9. Find common ground and discuss mutual goals. Co-generated projects should yield mutuality - in other words - all parties involved should feel that they are benefiting from the experience.

10. Make a commitment, set timelines, and discuss responsibilities. These elements should be formalized and operationalized in writing for clarity, documentation, and accountability. Honoring responsibilities engenders trust and establishes mutual respect.

Joel

Initial phone conversations about IN*SOURCE helping launch FAF with Cristina instilled confidence in her approach to working with families. Broad mutual interest was established that included what was effectively an effort to establish parent perspective authoritatively in the curriculum of pre-service special education teachers at a major university. This was a gift, but Cristina's careful positioning and awareness of power differentials did not make it feel forced as it had with other researchers who had taken time to answer my questions. Rather, I see the FAF launch as a 
collaboration in every mutual sense of the word. From an IN*SOURCE perspective, there was no easily discernible or realistic path toward realizing the opportunity to participate in the education of future special educators that Cristina was offering. Yet, this opportunity resonated so clearly with the persistent challenges around appropriate parent involvement within special education, which is one of the very reasons why organizations like IN*SOURCE exist.

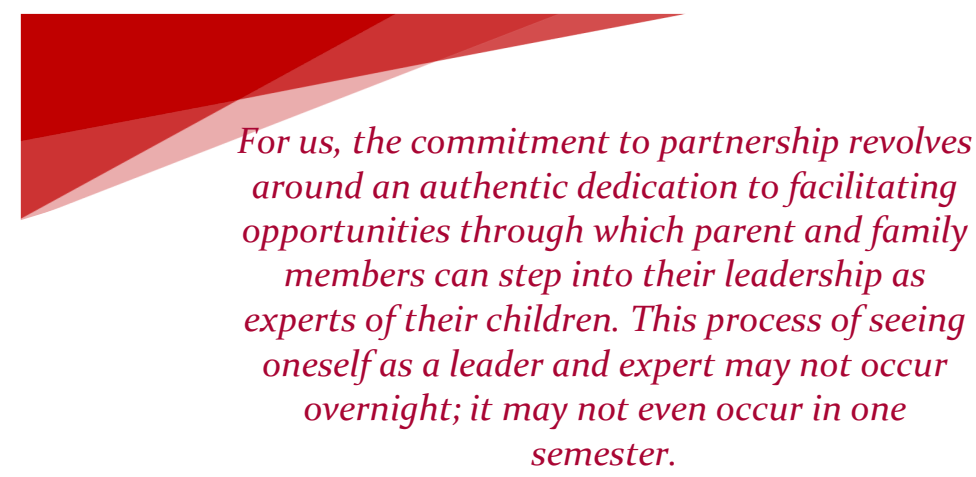

The broad mutual interest established with Cristina was fed by the thorough vetting of her requests for access to families we've worked with and endorsement of the FAF project by our organization. Trust was extended both ways during this process, and while I was most aware of and concerned about Cristina's intentions and process with her study, it was also apparent that she was investing valuable time and energy. As Cristina's commitment to these principles became increasingly evident, my desire to see her work thrive grew. While she was not a parent to children with dis/abilities, she was clearly in this for the long haul, and we wanted Cristina centrally involved in our organization's work beyond the FAF project. Cristina provided letters of support for the interpreter program mentioned above and concurrently Cristina joined IN*SOURCE’s board of directors.

\section{CREATING MUTUAL GOALS}

In this section, we begin by providing context for Family as Faculty's (FAF's) first iteration (2016 2017) to demonstrate the careful decisions made to guarantee that the partnership between Cristina, representing her university, and Joel, representing IN*SOURCE, remained mutually beneficial. We also give specifics of the project to provide more background about ways FAF has been conceptualized to include parents as co-educators in university courses. We draw attention to Figure 4 which delineates Cristina's and Joel's initial goals they created individually as they each thought about FAF and its intended outcomes. Then, we describe how these individual goals became shared ones that eventually drove and continue driving other FAF projects.

Before the first Family as Faculty project began in fall 2016, Cristina, as stated earlier, contacted IN*SOURCE and made a strong connection with Joel and the executive director. Cristina shared her FAF draft proposal with them. In it, were initial goals and intended outcomes she had created based on existing FAF educational literature. She wrote these for a small, internal grant she was applying for and was eventually awarded. She had initially contacted IN*SOURCE during the application process because she was interested in partnering with a parent-to-parent community organization to implement the FAF study. The goals she wrote were centered on data collection procedures used to measure changes in both pre- 
service teachers and parent co-educators over a 16week period (See Figure 4).

Figure 4

Family as Faculty: Creating Mutual Goals \& Their Intended Outcomes

\begin{tabular}{|c|c|}
\hline 1. Cristina's Initial Goals & Intended Outcomes \\
\hline $\begin{array}{l}\text { a) To change pre-service special } \\
\text { education teachers' views of } \\
\text { families of children with } \\
\text { disabilities from deficit- to } \\
\text { asset-based. }\end{array}$ & $\begin{array}{l}\text { To demonstrate a change in pre- } \\
\text { service teachers' dispositions } \\
\text { using a pre- and post-beliefs' } \\
\text { survey and journal reflections. }\end{array}$ \\
\hline $\begin{array}{l}\text { b) To position family members } \\
\text { of children with disabilities as } \\
\text { leaders and co-educators in a } \\
\text { special education course on } \\
\text { families. }\end{array}$ & $\begin{array}{l}\text { For parent co-educators to plan, } \\
\text { organize, and teach specific } \\
\text { classes in the course on families } \\
\text { with the hope that they would } \\
\text { experience a greater sense of self- } \\
\text { efficacy and empowerment. }\end{array}$ \\
\hline 2. Joel's Initial Goals & Intended Outcomes \\
\hline $\begin{array}{l}\text { a) To assist parents in } \\
\text { understanding their educational } \\
\text { rights. }\end{array}$ & $\begin{array}{l}\text { For parent co-educators to learn } \\
\text { more about their rights under } \\
\text { the special education law by } \\
\text { teaching future special education } \\
\text { teachers. }\end{array}$ \\
\hline $\begin{array}{l}\text { b) To give parents information } \\
\text { about the special education } \\
\text { process. }\end{array}$ & $\begin{array}{l}\text { In line with (a), for parent co- } \\
\text { educators to be able to articulate } \\
\text { how processes described in state } \\
\text { special education law pertain to } \\
\text { their specific experiences. }\end{array}$ \\
\hline $\begin{array}{l}\text { c) To help parents and schools } \\
\text { work together and develop } \\
\text { positive relationships. }\end{array}$ & $\begin{array}{l}\text { Through FAF, parents, in } \\
\text { speaking with future special } \\
\text { educators, will practice effective } \\
\text { communication and } \\
\text { interpersonal skills centered on } \\
\text { parent/family-teacher } \\
\text { collaboration. }\end{array}$ \\
\hline $\begin{array}{l}\text { d) To assist parents in becoming } \\
\text { better advocates for their } \\
\text { children. }\end{array}$ & $\begin{array}{l}\text { Through FAF, parents will use } \\
\text { their voice to tell their stories } \\
\text { and feel more confident in their } \\
\text { agency. }\end{array}$ \\
\hline 3. Mutual Goals Created & Intended Outcomes \\
\hline $\begin{array}{l}\text { a) To structure opportunities for } \\
\text { parents/family members to step } \\
\text { into leadership roles in higher } \\
\text { education settings. }\end{array}$ & $\begin{array}{l}\text { Through FAF, parents/family } \\
\text { members will plan, organize, and } \\
\text { teach classes on specific topics in } \\
\text { a university special education } \\
\text { course. }\end{array}$ \\
\hline $\begin{array}{l}\text { b) To organize specific activities } \\
\text { through FAF for future special } \\
\text { education teachers to develop } \\
\text { an awareness of family rights } \\
\text { and advocacy. }\end{array}$ & $\begin{array}{l}\text { Classes led by parent co- } \\
\text { educators will focus on topics of } \\
\text { family rights and advocacy as } \\
\text { presented through lived } \\
\text { experience, case studies, and } \\
\text { activities grounded in special } \\
\text { education law. }\end{array}$ \\
\hline $\begin{array}{l}\text { c) For Cristina and Joel to } \\
\text { maintain on-going structured } \\
\text { commitments to support each } \\
\text { other's projects and } \\
\text { organizations. }\end{array}$ & $\begin{array}{l}\text { Cristina demonstrates support by } \\
\text { becoming a board member of } \\
\text { IN*SOURCE. Joel commits to } \\
\text { writing continuous letters of } \\
\text { support. Both work together on } \\
\text { grants, conference presentations, } \\
\text { and manuscripts. }\end{array}$ \\
\hline
\end{tabular}

These goals and their intended outcomes impacted 22 pre-service teachers who were mostly white, middle-class, females and 8 parent participants. Of these eight, there were 7 females and 1 male. Of the females, there were 2 Latinas ( 1 from Nicaragua and 1 from Mexico) and one African American. In this first FAF project, the parents attended co-planning sessions in which they chose and organized content. Content centered on special education topics linked to course standards included, but were not limited to: collaboration, inclusive practices, disproportionality, ableism, medical treatments, communication with school administrators and teachers, and culture and language barriers. The course was structured so parents could present in pairs or triads. Four classes of 2 hour 40 minute periods in the 16-week course were dedicated to these parent-led class sessions. Parent as co-educators taught pre-service special education teachers specific course content from their insider lens and expertise of their child.

\section{Before the implementation of the first FAF} project, however, Joel asked Cristina questions about some of the parent presenters who were also parent advocates/trainers for IN*SOURCE. He wanted to ensure that the parent presenters were supported by IN*SOURCE in direct and tangible ways. For example, he provided specific parent presenters with printed copies of the state education law to use in FAF parentled discussions for the pre-service teachers. He also gave access to specific PowerPoints parents could use to ground their information in law and policy. Through multiple conversations, Joel made clear some of IN*SOURCE’s main goals that he hoped to see 
addressed through the FAF projects (See Figure 4). Cristina found these goals to be very important from an educator perspective. Over several conversations with Joel, she described how these goals could also be written for pre-service teachers and other educators. Future teachers, like parents, needed to know information about the special education process and how to work collaboratively with others to develop positive relationships. With these goals in mind, Cristina and Joel discussed ways their individual goals and intended outcomes could merge to create mutual ones. Mutual goals, for Cristina and Joel, meant an intentional integration of conceptual understandings and concrete outcomes that would benefit each of them in relation to their professional commitments. They developed three. The first two were structured through FAF parent/family-led sessions that focused on special education topics parents chose to teach. The last mutual goal was Cristina's and Joel's commitment to one another which entailed several ways that each of them would be supportive and accountable to each other's organization or projects (See Figure 4).

\section{MAKING SUSTAINABLE COMMITMENTS}

In community-engaged partnerships, sustainability is crucial in maintaining long-term commitments through which mutually established goals can be realized. Though short-term goals are necessary for taking first steps toward accomplishing concrete, timely actions, long-term goals require honoring processes that may take an extended period of time. For us, the commitment to partnership revolves around an authentic dedication to facilitating opportunities through which parent and family members can step into their leadership as experts of their children. This process of seeing oneself as a leader and expert may not occur overnight; it may not even occur in one semester. For this reason, we think of Family as Faculty as a 5- or 10-year project in which there are many iterations. Even though certain funding mechanisms are structured to provide monies for 1year increments, Cristina, in particular, conceptualizes each year as one part of a larger whole through which parents and family members progress toward leadership in higher educational spaces. Sustainability in the context of FAF means working with and learning from parents year after year as co-educators who enrich the overall project.

Sustainable, mutually founded commitments have been at the heart of our partnership. Here we take a moment to discuss the ways we have been consistently supportive of one another's projects. Specific questions that we have asked ourselves over the past three years are shared in Figure 5 to assist others who are interested in establishing long-term commitments with community or university partners.

Figure 5:

Sustainable Commitments: What Questions to Ask

1. Have mutual goals been established, operationalized, and formalized (in some manner)?

2. Do these mutual goals have timelines attached? Are these timelines realistic? Are they fair to all stakeholders?

\footnotetext{
3. Has there been a discussion around what an enduring partnership around these goals may look like?

4. Do these mutual goals state who is responsible for implementing and carrying them out? Are the responsibilities equitably distributed?

5. Has there been a conversation around accountability? What does accountability mean for each person? What does accountability mean for implementation of and follow through of mutual goals?
} 
6. Is there some type of memorandum of understanding (MOU) between you and your partner? Is it easily accessible? Is the language clear?

7. Does the MOU reflect a shared vision and mutual goals?

8. What structures or mechanisms have been put in place to ensure mutual goals are realized?

9. Where do meetings about accountability, long-term commitments, and mutual goals take place? How does location impact enduring partnerships?

10. Is there room for the commitments to evolve and transform as the project grows or changes?

In the academic year 2017 - 2018, Joel became the Executive Director of IN*SOURCE. In his new leadership role, he has written comprehensive letters of support for Cristina. Cristina has been awarded several community-engaged grants and fellowships due in part to IN*SOURCE’s demonstrated commitment to the FAF projects. Further IN*SOURCE has given in-kind matches to these grants consisting of administrative and staff support, material resources, and transportation costs. Continued funding has allowed Cristina to expand FAF and to continue working with parents affiliated with IN*SOURCE. In fall 2017 graduate students, parents of children with dis/abilities, and community stakeholders affiliated with local parent-to-parent organizations collaborated together to organize and host an Inclusion Conference for over 130 participants. IN*SOURCE was prominently featured in conference panels and family-led discussions.

The 2018 - 2019 FAF project that is currently underway consists of multiple stakeholder groups including: a) IN*SOURCE and a local parent-to-parent organization; b) undergraduate pre-service special education teachers; c) graduate in-service teachers and educators; d) undergraduate students acting as interpreters/translators from the Latino Studies Department; e) parent educators from previous FAF projects; and f) 18 Latinx family members of children with Down Syndrome and Autism. Extensive support from IN*SOURCE has been necessary in securing funding and specific structural supports needed to implement this complex study involving over 70 stakeholders. One main purpose of this third iteration of FAF is to support Latinx families through ongoing family-driven workshops. Latinx parent participants are either Spanish/English bilingual or monolingual Spanish speakers learning English as a new language. This year's project focuses on family-driven miniaction plans through which these parents, with the support of students, create short- and long-term goals to address challenges their children with dis/abilities are experiencing in schools. IN*SOURCE, under Joel's leadership, has connected Cristina to several bilingual parent advocates who are instrumental to the overall planning and implementation of this project.

In turn, Cristina has demonstrated specific commitments to IN*SOURCE described in the next section that contribute to the organization's overall stability and sustainability. For example, she has given extensive time and energy to IN*SOURCE's organization to ensure its long-term, fiscal solvency by writing letters of support, co-writing grants with Joel, and connecting IN*SOURCE with university-based centers to enhance its reputation as an equity-centered organization. Further, she has established and maintained strong relationships with IN*SOURCE's 
board members and staff and continues to co-teach with parents affiliated directly with this organization.

mutually defined and beneficial goals are the center of all discussions. Perhaps the equivalent "effort" of 6 hours shows up in a different manner, for example, in

\section{ATTENDING TO}

\section{RECIPROCITY}

Reciprocity is

an intentional choice

and act between

stakeholders of

giving time, energy,

and resources to the

other while receiving

a proportionate

"return" of service.

Reciprocity, to us,

should not be

measured and

scrutinized solely in

strict, quantitative

terms. For example, if

we give 6 hours of

volunteer time to our partner we should not expect

them to return an exact equivalent as measured in the

same form. From the outside, this input/output

mechanism of measuring effort may appear "equal"

but, in practice, it can feel forced and disingenuous.

We conceptualize this "mechanism" as a fulcrum as

shown in Figure 6, whereby a balanced partnership can

only be maintained if the effort exerted is equivalent to

the load or responsibility carried.

Reciprocity in a community partnership should

be a dynamic process in which negotiation between

stakeholders is conducted respectfully, whereby providing "free"

recruitment for the

partner's project at a

state conference.

Time, energy, and

resources should be

given and received

within a continuous

flow that makes

sense to the

everyday activities

and choices being

made to sustain a

healthy and

equitable

partnership.

Additionally, intent, integrity, and accountability are core, underlying elements of reciprocity that drive meaningful and authentic relationships. Simply stated, if we, as community partners, can say with $100 \%$ confidence that "we have each other's backs" and "we can count on one another" then we know internally that the relationships are sustainable and balanced.

\section{Reciprocity to Parents in FAF}

In all FAF projects, Cristina has been able to provide monetary compensation to parent participants to demonstrate she values their expertise as professionals who are contributing to the overall FAF research. When Cristina shared the initial FAF 
proposal with Joel in 2016, one of the points of conversation was payment and its distribution.

Cristina explained that paying the parent co-educators was an important gesture to show she deeply respected their knowledge, time, and curricular and instructional contributions. Cristina was adamant that, in spite of certain parents assuring her that they "didn't need the money in order to participate," she wanted to show she recognized the importance of their participation in the course. Paying them for their expert input and time was an act of reciprocity. Moreover, the parents trusted Cristina with their lived experiences. They willingly shared their stories with pre-service special education teachers. In turn, Cristina demonstrated to parents that their expertise was just as, if not more, important. She did this by replacing "traditional" course content with parents' first-hand narratives. Joel was appreciative of these actions and stated how important it was to value parents' contributions as experts of their children in FAF projects.

\section{Reciprocity in Partnerships}

Specific to our partnership, there have been several moments we want to highlight that are tangible acts of reciprocity. During the first iteration of the FAF project after Joel had sent out the email to assist Cristina in recruiting parents, he asked her for a letter of support for a grant he was writing for a language interpreter program mentioned earlier. This program was designed to prepare special education interpreters to "build cultural bridges" within their schools to better facilitate special education case conferences with schools and families. Cristina felt qualified to recommend this program because of her bilingual special education background. Fortuitously, IN*SOURCE was awarded funding to implement this program. In line with reciprocity being given and received "within a continuous flow that makes sense," (Joel, email correspondence) we benefited from assisting one another in meeting individual goals that contributed to supporting families in our respective projects.

Another act of "reciprocity" was Cristina's board member application submission to IN*SOURCE. She wrote a comprehensive cover letter detailing the ways she could contribute directly to ADVOCATE's mission: "to provide parents, families, individuals \& service providers in the state of Indiana the information \& training necessary to help assure effective educational programs \& appropriate services for individuals with disabilities." The former Executive Director and the IN*SOURCE Board of Directors voted on and accepted her application. Since 2016, Cristina has been serving on IN*SOURCE's board and, since 2017, has acted as Secretary.

Finally, we presented together at a regional conference held in Las Vegas for parent training and information centers interested in unique opportunities for partnerships to benefit families. Our presentation focused on the FAF project and our collaboration as university-community member partners. In addition, we recently wrote and submitted a Department of Education Grant for a Statewide Family Engagement Center. Though we were not awarded this grant, we collaborated with several other stakeholders including a federally-funded, Equity Assistance Center. 


\section{ADDRESSING POWER DYNAMICS}

In this section, it is helpful to refer to Figures 2 and 6 to understand the balance and distribution of power in university-community partnerships. Here Cristina and Joel extend their understandings of mutual respect and reciprocity by bringing up specific issues related to power. For Cristina, the discussion is focused on tensions emerging from communityengaged work originating from dominant, Eurocentric university structures and applied to community settings. Joel speaks to the inherent dichotomy of "running a business" versus helping families. However, he centers his narrative on ways that power can be shared in order to attend to both the business of IN*SOURCE and its mission, the latter being focused on parent advocacy.

\section{Cristina}

Power dynamics must be accounted for in all community-engaged relationships, specifically university-community partnerships. Though I cannot speak for all service-learning or community-based projects originating out of universities, I can describe my own evolving understandings of power as I reflect on the ways I've needed to problematize the university's role in my own FAF projects. There are major tensions in my work with families as I integrate community-engaged activities within a "servicelearning" course. Here, service-learning is defined as, "An instructional approach that is credit bearing and linking curriculum goals with intentional learning within the community" (Delano-Oriaran, 2015, p. 38). By intentionally situating FAF approaches in my courses, I become accountable to university constructs that limit the amount of time allotted for FAF projects. In other words: Is it really possible to do authentic community-engaged projects with families and students when I only have 16-week chunks of time to build and develop relationships?

Another tension is constructing genuine ways to assess students. Because of university norms, I need to evaluate students' performance and learning through grades. In community-engaged work, "grading" students on the process of building important student-family partnerships seems contrary to the purpose of my work. I want relationships to develop authentically. When students "do communityengaged work" to demonstrate course expectations to "get the good grade" then the energy they bring to their "engagement" is rooted in obligation rather than in genuine acts of caring, consideration, empathy, respect, and trust. Conversely, when students are open to learning about and from community partners as a means to expand their own understandings and to fully embrace the collaboration process through dialogic interactions, then, I believe, authentic beginnings for engagement are possible.

As an instructor who intentionally situates FAF approaches as pedagogical tools for learning, I need to be extremely aware of uneven power dynamics (Cummins, 2009). Embedded within these dynamics between students and community stakeholders is the potentiality for "service" to be done for communities perceived in be in need of help or "damaged" in some way (Koster, Baccar, \& Lemelin, 2012; Tuck, 2009). Knowing that traditional service-learning is an institutional practice historically connected to 
dominant Eurocentric values is an important part of conscious awareness in engaging with communities (Leeuw, S. D., Cameron, E. S., \& Greenwood, M. L., 2012). When service-learning projects are not centered in social justice and equity, they become extensions of Eurocentric, colonizing practices (Mitchell, 2008, 2014). If equity and social justice are not considered in community-engaged work originating in or from the university then "the work" can potentially harm the community stakeholders for whom it was designed.

Even with pure intention to expose my students to community-engaged work co-constructed with stakeholders, I know these experiences designed for university-level courses may not be enough to disrupt deficit-driven beliefs of parents and families. Further, what keeps me up at night is thinking about whether or not working within university course parameters allows for true reciprocity with community stakeholders. Is the work I am doing truly beneficial for the parents, families and community partners with whom I collaborate? Even when I intentionally institute measures to center stakeholders' voices in my work, is the work equitable on all levels or do some individuals feel excluded or marginalized? Though I embed several opportunities to collect data from stakeholders in my FAF studies about how and if they believe they are benefiting from the FAF projects, sometimes I wonder if these opportunities reach deep enough to unearth the complexities of their answers.

\section{Joel}

While IN*SOURCE is a 501c3, for many practical purposes we are a business. We have employees, a website and a 1-8oo number, operate with contracts and invoices, have hours of operation, company laptops, reimbursement protocols, and so on. While IN*SOURCE is concerned with efficiency and fiscal sustainability, we do not turn dollars into products or services in order to make a profit. Rather, we turn dollars into products and services in order to help families. Any mutually beneficial relationship needs to account for that governing purpose. Grant and contract stipulations also inform what mutual benefit means to IN`SOURCE. Tellingly grant and contract funded work is often referred to as a "project" and often functions as a mediating expression of all that might be done toward fulfilling IN*SOURCE’s mission and what there are resources to do. Realizing a mutually beneficial partnership may help get to project deliverables more efficiently, which from the "business" aspect of being a nonprofit is, of course, helpful. All the better, however, if a mutually realized benefit can do what you do not have any business or project capacity for yet is fully aligned with mission. While the FAF did help with project deliverables, the latter is what FAF really represented for IN*SOURCE.

\section{CONCLUSIONS: WHAT'S NEXT?}

At the heart of our work is the understanding that families of children with dis/abilities are strong advocates for their children who deserve respect and integrity from educational professionals in decisions impacting their child. We interpret Section 300.300(a)(2)(iii) of the Individuals with Disabilities Education and Improvement Act (IDEIA) to mean that parents are equal stakeholders and should be given every opportunity to voice their concerns, contribute 
to their child's specific school-related goals and objectives, be actively and seriously listened to for their unique insights, and have equitable access to power structures that inform their child's academic and educational trajectory.

Figure 7

Through our

mutually respectful

partnership, we are

creating innovative

pathways for families to

participate as leaders and

knowledge-makers in

special education teacher

preparation courses. We

understand that in

partnership our work

with families is enhanced

as we consider options

that we had not

conceived of before or

were unable to enact

without one another's

support. As we look to the future, we are interested in

expanding Family as Faculty and other programs that

center families' voice in educational spaces. We are

committed to opening more doors for historically

minoritized families to engage in and influence

programs at the local and state level, in the classrooms,

and at higher education institutions. In practice, this

engagement means listening to families from diverse

cultural, linguistic, racial and ethnic backgrounds and

collaborating with them to shape future iterations of

programs like FAF. By doing so we hope to genuinely address areas these families have identified and want to pursue that, ultimately, will benefit their children and others with dis/abilities.

\section{FURTHER EXPLORATIONS}

While we describe a successful instance of a mutually respectful universitycommunity partnership, we believe further research and exploration of this topic is warranted within the field of special education and beyond. The underlying values of equity including mutual respect, reciprocity, and sustainability inform this partnership, are relevant to other fields of study, and need to be more fully realized within special education. In Figure 7 we provide some concrete examples of how we are thinking about applying these values to our future collaborative work as well as how these values may be considered in others' community-engaged projects.

Future inquiries might also interact with the substantial mutual benefit for both partners in that the approach by Cristina was iterative but not transactional and focused but not brief. Simply, a mutually respectful approach toward a community partner takes time but pays off, and indeed this and other successful university-community partnerships 
undergirded by equity ideas must make pragmatic sense in order to persist. What other insights can be gleaned by examining the intersection of equity and practicality? And how can this examination inform and transform spaces for genuine, sustainable partnerships?

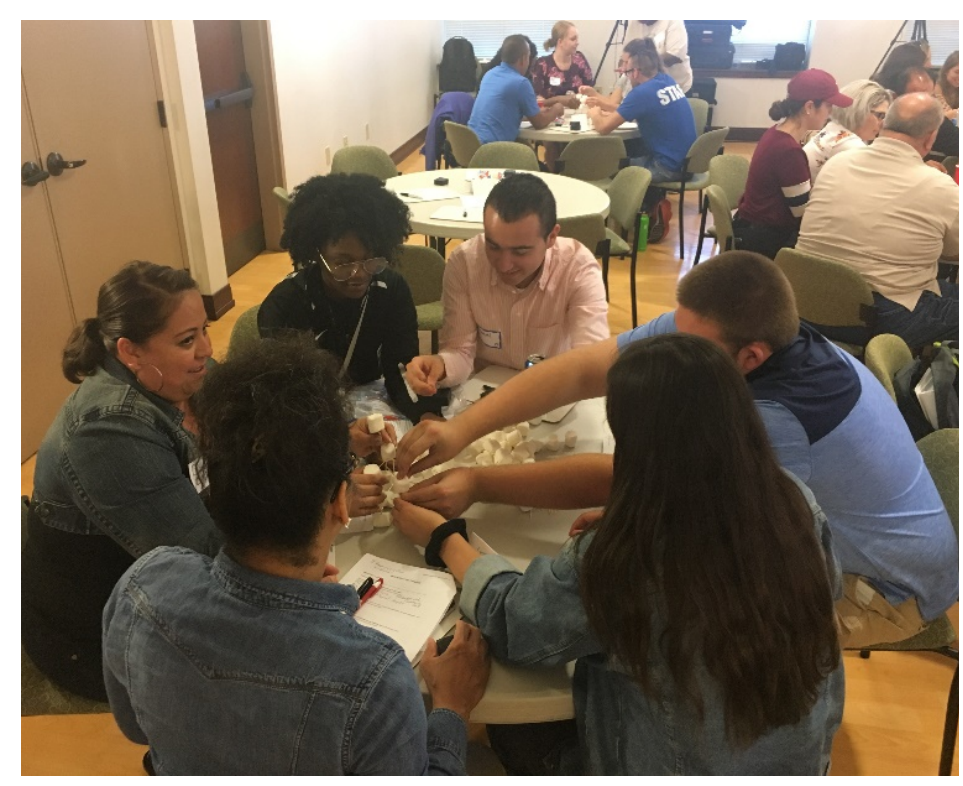

Students and parents work together to build the tallest, free-standing structure with the materials provided.

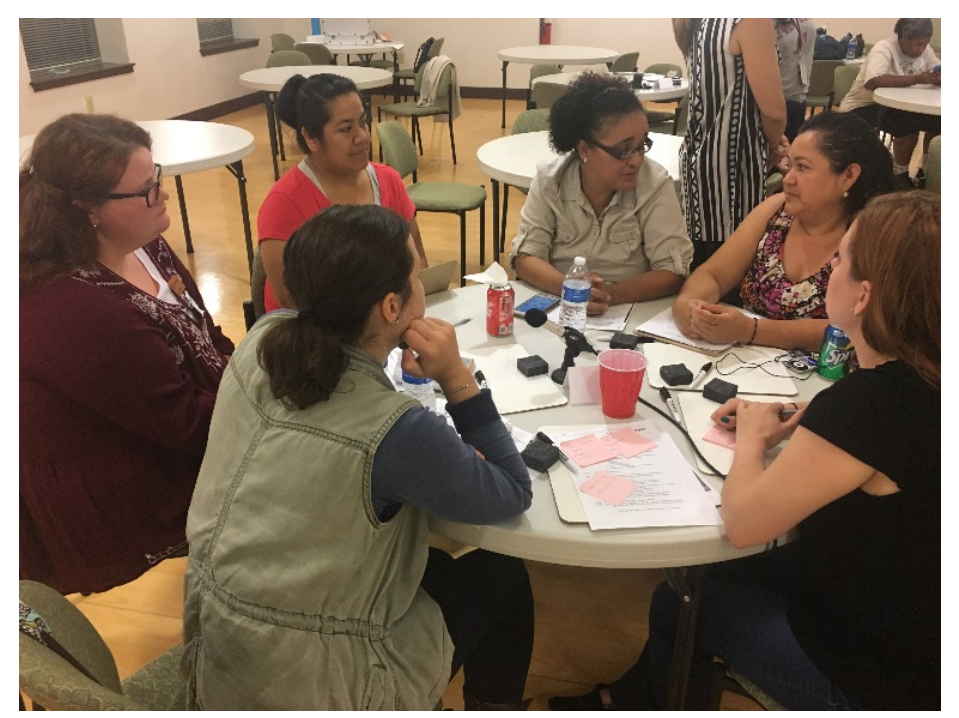

Students and parents are working together on mini-action plans centered on family-driven goals. 


\section{REFERENCES}

Clandinin, D. J., Cave, M. T., \& Berendonk, C. (2017). Narrative inquiry: A relational research methodology for medical education. Medical Education, 2017(51), 89-96.

Clandinin, D. J. \& Huber, J. (2010). Narrative inquiry. In B. McGraw, E. Baker \& P. Peterson (Eds), International encyclopedia of education third ed.). New York, NY: Elsevier.

https://doi.org/10.1016/B978-0-08-0448947.01387-7

Clandinin, D. J. \& Rosiek, J. (2007). Mapping is a landscape of narrative inquiry. Journal of Teacher Education, 58:1, 21-35.

https://doi.org/10.1177/0022487106296218

Cummins, J. (2009). Pedagogies of choice: Challenging coercive relations of power in classroom and communities. International Journal of Bilingual Education and Bilingualism, 12(3), 261 - 271.

Davis, L. J. (1995). Enforcing normalcy: Disability, deafness and the body. London: Verso.

Davis, L. J. (2013). The end of identity politics: On disability as an unstable category. In L.J. Davis (Ed.), The disability studies reader (pp. 263277). New York: Routledge.

Delano-Oriaran, O. (2015). An overview of academic community-based learning approaches. In O. Delano-Oriaran, M. W. Penick-Parks, \& S. Fondrie (Eds.), Foundations of Service-Learning and Civic Engagement (pp. 37 - 45). Los Angeles, CA: Sage Publications, Inc.

Heller, R., McKlindon, D. (1996). Families as "faculty": parents educating caregivers about familycentered care. Pediatric Nursing, 22(5), 428-431.

Fals-Borda, O. (2006). The North-South convergence: A 30-year first-person assessment of PAR. Action Research, 4(3), 351-358.

Fals-Borda, O. (1987). The application of participatory action research in Latin America. International Sociology, 2(4), 329-347.

Forlin, C., \& Hopewell, T. (2006). Inclusion - the heart of the matter: Perceptions of a parent's journey. British Journal of Special Education, 33(2), $55-61$.

Freire, P. (1970/2000). Pedagogy of the oppressed (30 ${ }^{\text {th }}$ anniversary edition). New York: Bloomsbury.

Johnson, A. M., Yoder, J., \& Richardson-Nassif (2006). Using families as faculty in teaching medical students family-centered care: What are students learning? Teaching $\mathcal{E}$ Learning in Medicine, 18(3), $222-225$.

Koster, R., Baccar, K., \& Lemelin, R. H. (2012). Moving from research ON, to research WITH and FOR Indigenous communities: A critical reflection on community-based participatory research. The Canadian Geographer/Le Géographe canadien, 56(2), 195-210. 
Leeuw, S. D., Cameron, E. S., \& Greenwood, M. L. (2012). Participatory and community-based research, Indigenous geographies, and the spaces of friendship: A critical engagement. The Canadian Geographer/Le Géographe canadien, 56(2), 180-194.

Macy, M., \& Squires, J. (2009). L’arte D’arrangiarsi: Evaluation of an innovative practice in a preservice practicum. Journal of Early Intervention, 31(4), $308-325$.

Mitchell, T. D. (2008). Traditional vs. critical servicelearning: Engaging the literature to differentiate two models. Michigan Journal of Community Service Learning, 14(2), 50-65.

Mitchell, T. D. (2014). How service-learning enacts social justice sensemaking. Journal of Critical Thought and Praxis, 2(2), Available at: http://lib.dr.iastate.edu/jctp/vol2/iss2/6

Patterson, K. B., Webb, K. W., \& Krudwig, K. M. (2009). Family as faculty parents: Influence on teachers' beliefs about family partnerships. Preventing School Failure, 54(1), 41 - 50.

Santamaría Graff, C. \& Vazquez, S. L. (2014). Family resistance as a tool in urban school reform. In E. B. Kozleski \& K. King Thorius (Eds.), Ability, equity, and culture: Sustaining inclusive urban education reform. New York: Teachers College Press

Santamaría Graff, C., McCain, T., \& Gomez-Vilchis, V. (2013). Latina resilience in higher education: Contributing factors including seasonal farmworker experiences. Journal of Hispanic Higher Education, 12(4), 334 - 344. DOI 10.1177/1538192713494212

Santamaria, C. (2009). Mexican origin parents with special needs children: Using a critically compassionate intellectualism model to support and foster their participation in U.S. schools through a participatory action research project. Dissertation Abstracts International, $70(4), 474$

Tuck, E. (2009). Suspending damage: A letter to communities. Harvard Educational Review, $79(3), 409-427$.

Warren-Gordon, K., \& Santamaría Graff, C. (2018, Nov/Dec). Critical Service-Learning as a vehicle for change in higher education courses. Changes, $50(60), 20 \quad-$ 23. DOI: 10.1080/ooo91383.2018.1540817

Williams, E. (2012). Encouraging discussion between teacher candidates and families with exceptional children. Education, 133(2), 239 247 . 